\title{
APOBEC3B Gene
}

National Cancer Institute

\section{Source}

National Cancer Institute. APOBEC3B Gene. NCI Thesaurus. Code C117001.

This gene plays a role in viral DNA cytosine deamination. 